\title{
A Crise no Setor Público e o Futuro da Pesquisa em Saúde
}

\author{
Nilson do Rosário Costa *
}

Quais os efeitos da atual crise no setor público sobre o futuro da produção científica em saúde públi$\mathrm{ca}$ ? Que amargas conseqüências o estrangulamento financeiro e moral dos serviços públicos trará sobre salários, infra-estrutura física e recursos para a pesquisa e ensino nos próximos anos?

Os impactos dessa crise não podem obviamente ser compreendidos de maneira restrita ao setor saúde e ao nível da Fiocruz/Ensp. Devem ser pensados no âmbito de uma ofensiva do discurso neoliberal a respeito do papel da esfera pública em nosso país. Para esse discurso, o "mercado" e a privatização são as panacéias para a cura de todos os males: as atividades públicas compõem um todo indiferenciado, parasitário e perdulário. Essa ótica conservadora põe comodamente no mesmo saco tanto empresas estatais inúteis e deficitárias - usinas nucleares, por exemplo - como centros de excelência na pesquisa científica ou hospitais públicos para doentes crônicos. Qual proposta tem esse discurso para o prometido resgate da dívida social do país?

Talvez promover o crescimento, a modernização industrial e a integração à economia mundial, esperando que esse movimento, pela via do mercado, universalize os frutos da prosperidade. Cabe perguntar se em algum lugar do mundo foi performado esse milagre. A té agora não se tem registro histórico de tal experiência. Ademais, não temos muito boas lembranças sobre as promessas de crescimento de bolo da economia e o milagre $\mathrm{n} \nexists$ distribuição dos pães.

Ora, nurca é tarde lembrar que todo processo de consolidaçầo de uma economia nacional e de ampliação de direitos sociais de cidadania exigiu uma forte presença da função pública na produçã̃o de bens $e$ serviços. A característica central dessa produção é que ela se viabilizou fora da lógica do mercado, ou seja, na contramão da estrita razão do cálculo econômico.

Coube às políticas sociais, científicas e econômicas tomarem realidade os interesses que confrontaram a lógica da rentabilidade imediata ou a possessividade empresarial.

Não resta dúvida que durante décadas a idéia de "público" foi profundamente desgastada pela sistemática negaçāo das instituições a pensar o sentido social de suas práticas ou mesmo a baixíssima produti-

Cadernos de Saúde Pública, RJ, 6 (2) : 115-116, abr/jun, 1990
* Pesquisador da Ensp/Fiocruz e Vice-presidente da Associaçäo Brasilsira de Pós-Graduaçāo em Saúde Coletiva (Abrasco). 
vidade de suas atividades. A vasta tradição de uso patrimonialista pelas elites e pelas corporações profissionais das instituições fez com que se tormasse parte da ética do serviço público a recusa a qualquer propósito de avaliação, julgamento ou compromisso social.

Não há dúvida que nessa "cultura" cotidiana das instituições está a outra face da crise: a incômoda interpelação a respeito de absenteísmo, de qualidade do trabalho, produtividade etc, que encontra eco e respaldo na opinião pública.

Embora o tom levemente histérico dessa interpelação tente explicar os problemas da inflação, da pobreza, dos baixos salários como decorrência direta da presença do setor público na economia. O que é uma grosseira simplificação.

Ainda assim a generalização desse diagnóstico sobre a incompetência e nocividade da esfera pública tem produzido um resultado extremamente tortuoso na percepção imediata da população e dos formadores de opiniẫo. Parece, hoje, uma verdade incontomável considerar tudo que é "privado" como bom e virtuoso. E tudo que é público nocivo e impuro. $O$ que pode tomar natural a violenta implosão de todo acervo cultural, científico e tecnológico das várias e sérias instituições públicas do país.

Nesse ponto pode-se sugerir que as iniciativas políticas em defesa da pesquisa, da produção e do ensino públicos do país devam assumir alguns compromissos que foram muito desconsiderados na trajetória de muitas instituiçōes. É necessário, primeiro, tomar visíveis, públicas, as avaliaçōes periódicas do conjunto das atividades de pesquisa científica, desenvolvimento tecnológico e ensino desenvolvidas pela esfera pública; segundo, ampliar o uso de critérios de competência e mérito na ordenação e orientação da política de recursos humanos, especialmente no que diz respeito a promoções e ampliação de quadros; terceiro, estimular o uso de alguns instrumentos de planejamento e programação na gestão das instituições, para que seja possível a articulação mínima das propostas de trabalho.

Assim, atenuando as vastas e ecléticas iniciativas setoriais que tornam extremamente confuso o perfil das instituições - quando o há - perante a sociedade. Que, em última análise, as sustenta através dos recursos públicos. Estes são compromissos mínimos que podem, pelo menos, servir para atravessar o crescente abismo entre a produção científica nas instituições do país e parcelas da população. E que devem ser preocupações fundamentais para uma defesa legítima da atividade pública nesses tempos de pragmatismo irresponsável. 